\title{
Alleviation of chilling injury in postharvest banana with protection materials
}

\author{
Juliana Domingues Lima1*, Danilo Eduardo Rozane', Eduardo Nardini Gomes, \\ Silvia Helena Modenese Gorla da Silva ${ }^{1}$, Ricardo Alfredo Kluge ${ }^{2}$ \\ ${ }^{1}$ Universidade Estadual Paulista “Júlio de Mesquita Filho”, UNESP, Câmpus Experimental de Registro. Rua Nélson Brihi Badur, n.430, Vila \\ Tupy, CEP 11.900-000, Registro, SP, Brazil. judlima@registro.unesp.br, danilorozane@registro.unesp.br, engomes@registro.unesp.br, \\ silvia@registro.unesp.br, 2Universidade de São Paulo, Escola Superior de Agricultura "Luiz de Queiroz", Dep. Ciências Biológicas. Av. Pádua \\ Dias, n. 11, CEP 13418-900, CP 9, Piracicaba, SP, Brazil. rakluge@usp.br
}

\section{A B S TR A C T}

\begin{abstract}
Storage of bananas at low temperature is limited due to the development of chilling injury (Cl). The purpose of this paper was to investigate the influence of different protection materials on occurrence of $\mathrm{Cl}$ and the characteristics of banana in postharvest. Current paper also investigated temperatures variations in bags. The experiments were conducted with fruits of Musa spp., cultivars Prata (AAB) and Nanica (AAA). Comprised a completely randomized $2 \times 3 \times 6$ factorial design, two cultivars, three temperatures $\left(5^{\circ} \mathrm{C}\right.$ or $10^{\circ} \mathrm{C}$ for 10 hours and $20^{\circ} \mathrm{C}$ constant) and five protection materials (blue transparent polyethylene, white non-woven fabric, white opaque polyethylene, bubble wrap, white laminated non-woven fabric) and control (without protection). The different protection materials kept the temperature inside at $1{ }^{\circ} \mathrm{C}$ higher than environment. The critical temperature for occurrence of chilling injury was $5^{\circ} \mathrm{C}$ for 'Prata' banana and $10^{\circ} \mathrm{C}$ for 'Nanica' banana. White laminated non-woven fabric induced lower $\mathrm{Cl}$ index and tended to maintain the peel color characteristics $\left(\mathrm{L}^{*}, \mathrm{C}^{*}\right.$ and $\left.\mathrm{h}^{\circ}\right)$ higher, compared to other protection materials. 'Nanica' fruits stored at $20^{\circ} \mathrm{C}$ bagged with white laminated non-woven fabric exhibited lower incidence of Crown rot. Other physicochemical characteristics evaluated were not influenced by low temperature and protection material, only by cultivar.
\end{abstract}

Keywords: Bagging, Browning peel, Musa spp., Low temperature, Storage

\section{INTRODUCTION}

The banana fruit is harvested and stored in a mature green state. Marketing is complicated by postharvest losses (Hailu et al., 2012). Shelf life extension of banana has been a problem for years due to its climacteric respiration pattern (Sen et al., 2012). Low temperature handling and storage are the most important physical method of postharvest management of banana (Hailu et al., 2013). Green bananas are shipped/stored at 13 to $14^{\circ} \mathrm{C}$ to delay ripening (Hailu et al., 2013) because are susceptibility to chilling temperature below $13^{\circ} \mathrm{C}$ (Sen et al., 2012; Wu et al., 2014).

Chilling injury (CI) becomes a major problem in marketability in the banana industry (Hashim et al., 2014). The most common visual CI symptoms include a dull gray peel color, ripening, flavor and increasing physical injury and peel and pulp browning (Hailu et al., 2013). Polyethylene of different densities polypropylene and polyvinyl chloride has been used in the packaging of fruits with direct effect on the permeability to gases and water vapor, with subsequent differential effects on the fruit quality (Mangaraj et al., 2009).

Plastic films have also been found to increase the shelf life (Hailu et al., 2012; Sahay et al., 2015; Sahay et al., 2017) and help the banana fruit tolerate temperatures below $13^{\circ} \mathrm{C}$ without exhibit CI. The cooking bananas keeps well for nearly 60 days at 9 or $10^{\circ} \mathrm{C}$, in a partially evacuated polyethylene bag (Hailu et al., 2013). The use of 16 and $10 \mu \mathrm{m}$ polyethylene films, associated with storage at 12 and $15^{\circ} \mathrm{C}$, shows a retention of the ripening process of the fruits of the cultivars FHIA-02 (AAAA) e Preciosa (PV 4285) (AAAB), (Siqueira et al., 2010), Tropical (AAAB) and Thap Maeo (AAB) (Siqueira et al., 2017).

The purpose of this paper was to investigate the influence of different protection materials on occurrence of CI

\footnotetext{
*Corresponding author:

Juliana Domingues Lima,Universidade Estadual Paulista “Júlio de Mesquita Filho”, UNESP, Câmpus Experimental de Registro. Rua Nélson Brihi Badur, n.430, Vila Tupy, CEP 11.900-000, Registro, SP, Brazil. E-mail: "judlima@registro.unesp.br"
}

Received: 28 January 2018; $\quad$ Accepted: 13 July 2018 
and the characteristics in banana in postharvest. Current paper also investigated temperatures variations in bags. It was thus expected to establish the best bagging material to protect the fruit from CI and improve the quality of banana.

\section{MATERIALS AND METHODS}

\section{Plant materials and experimental design}

The experiments were conducted with fruits of 70 bunches of Musa spp., AAB group, subgroup Prata, cv. Prata and Musa spp., AAA, Cavendish subgroup, cv. Nanica harvested on two plots in a $5^{\text {th }}$ crop cycle in Jacupiranga, state of São Paulo, Brazil (2443' 6.2' S and 48 $2^{\circ}$ '53.2' W). The bunchs were harvested with $30 \mathrm{~mm}$ diameter and sum thermal of 1005 and 917 degree-days, respectively, for the 'Prata' and "Nanica'.

The four central hands of each bunch were collected and cut into bouquets of five fruits, without any defect or blemish. The bouquets were then washed, dried and bagged with blue transparent polyethylene (BTP) with $3 \mu$ of thickness and highly transparent; white non-woven fabric (WNF) with $3 \mu$ of thickness and moderately transparent; white opaque polyethylene (WOP) with $60 \mu$ of thickness; bubble wrap (BW) with $3 \mu$ of thickness and highly transparent; white laminated non-woven fabric (WLNF) with $1 \mu$ of thickness and translucent. Bouquets without protection (WP) were the control. BTP, BW and WOP were manufactured with low density polyethylene, and WNF and WLNF with polypropylene, all sealed and non-perforated. After bagging, the fruits underwent different temperatures and exposure times, as follows: $5^{\circ} \mathrm{C}$ for 10 hours; $10^{\circ} \mathrm{C}$ for 10 hours, and $20^{\circ} \mathrm{C}$ (constant) in a refrigerated chamber. The experimental design was completely randomized in a factorial $2 \times 3$ x 6 (cultivar x temperature x protection material), with seven replications. The incidence of the Cladosporium spot and Crown rot due to occurring in only one cultivar were analyzed according to completely randomized in a factorial $3 \times 6$ (temperature $x$ protection material), with seven replications.

Temperatures were taken on the peel and pulp surface during low temperature exposure by a Datallogger with sensors, coupled to an automatic acquisition of periodic data readings. Until reached maturity stage 6 (von Loesecke, 1950), all plots were maintained at at $20^{\circ} \mathrm{C}$ and $90 \%$ relative humidity. The camera space was ventilated for 15 min every $12 \mathrm{~h}$ to avoid the build-up of ethylene.

\section{Evaluation of chilling injury and fruit peel color}

Assessments included the CI index characterized by relative extent of peel browning tissues on four individual fruits, using scale (1) $<25 \%$, (2) 25-50\%, (3) $>50 \%$ (Kondo et al., 2005). The peel color was measured at four points on each fruit peel using a colorimeter (CR-400, Minolta Co., Osaka, Japan) calibrated using a standard white plate. The illuminant was D65 and color recorded using the CIE $L^{*} a^{*} b^{*}$ system. L* denotes the brightness $(0=$ black and $100=$ white $)$ and chromatic co-ordinates $a^{*}\left(+a^{*}=\right.$ green and $\left.-\mathrm{a}^{*}=\mathrm{red}\right), b^{*}\left(+\mathrm{b}^{*}=\right.$ yellow and $-\mathrm{b}^{*}=$ blue $)$. The hue angle obtained as $\mathrm{h}^{\circ}=\tan ^{-1}\left(b^{*} / a^{*}\right)$ and the chromaticity as $C^{*}=\left(a^{* 2}+b^{* 2}\right)^{1 / 2}$, were calculated.

\section{Evaluation of physicochemical characteristics and phytosanitary quality of the fruits}

The shelf life, was defined as the time from harvest to when fruit reached the maturity stage 6; the mass loss, was determinated by the equation ML $=[(\mathrm{Mf}-\mathrm{Mi}) /$ Mi]*100, where Mi is the initial mass and Mf is mass at maturity; and the firmness of pulp, estimated with penetrometer equipped with conical probe of $0,8 \mathrm{~cm}$ diameter. The $\mathrm{pH}$ was determinated in $\mathrm{pH}$-meter after homogenization of pulp with water and the titratable acidity, after homogenization of pulp with water and titration with $\mathrm{NaOH}$ (AOAC, 2005); the total soluble solid, determined after homogenization of pulp with water using digital refractometer (Tressler and Joslyn, 1961). The soluble sugars were determined after extracting with hot ethanol and reaction with anthrone (Hodge and Hodfreiter, 1962), whiles starch, quantified in residue from ethanol extraction of soluble sugars (McCready et al., 1950; Patel, 1970). The incidence of rot (Cladosporium spot, Anthracnose and Crown rot) in mature fruits was also estimated. All analyses were made in triplicates.

\section{Statistical analysis}

Was carried out with Sisvar 4.2. Analysis of variance was then performed with F-test and the differences in means were compared by 'Tukey's test. The data of disease incidence were transformed in $\operatorname{arc} \operatorname{sen}(\mathrm{x} / 100)^{1 / 2}$. Correlation study (r) was performed by Pearson's method based on the significance of t-test.

\section{RESULTS AND DISCUSSION}

The analysis of the temperature near the surface of fruit peels at 10 and $5^{\circ} \mathrm{C}$ revealed no significant changes when comparing the temperatures of bagged fruit with different types. However, temperature rose when bagging was employed (Figure 1).

On an the average, the protection of fruits with different types of material kept the temperature higher by 0.71 and $0.66^{\circ} \mathrm{C}$ for banana cultivars 'Nanica' and 'Prata', respectively, when compared to fruits without protection 
during 10 hours exposure at $10^{\circ} \mathrm{C}$ (Figure 1). From 0.44 and $0.49^{\circ} \mathrm{C}$ during exposure to $5^{\circ} \mathrm{C}$, respectively. In short, there was a less than $1^{\circ} \mathrm{C}$ increase in temperature with bagging. During the exposure of fruits to 5 or $10^{\circ} \mathrm{C}$ during 10 hours, regardless of the cultivar, the temperature of the pulp was always higher than that of the peel.

CI index was influenced by interaction cultivar $\mathrm{x}$ temperature and (Table 1) and temperature $\mathrm{x}$ protection material (Table 2). For 'Prata' fruits, CI index was low at 10 and $20^{\circ} \mathrm{C}$ and increased at $5^{\circ} \mathrm{C}$, while for 'Nanica' increased already at $10^{\circ} \mathrm{C}$ and differed between the three temperatures of storage (Table 1). Regardless of temperature, CI index was always lower in fruits of the cv. Prata, indicating superior tolerance at low temperature.

For both cultivars, CI index increases with the reduction of storage temperature, regardless of the protection material used (Table 2). At $20^{\circ} \mathrm{C}$, there were no significant differences in $\mathrm{CI}$ index between the protection materials. However, at 5 and $10^{\circ} \mathrm{C}$, fruits protected with WLNF exhibited lower CI index.

Browning has a significant impact on colour of peel. L*, $\mathrm{C}^{*} \mathrm{e} \mathrm{h}^{\circ}$ were affected by interaction cultivar $\mathrm{x}$ temperature $\mathrm{x}$ material. The unfolding of interaction revealed there was a marked difference in color characteristics between the cultivars (Table 3). Regardless of temperature and protection materials, fruits 'Nanica' exhibited $L^{*}, C^{*}$ and $h^{\circ}$ lower than 'Prata', a sign of greater internal browning. $\mathrm{L}^{*}$ of fruits 'Prata' stored at $10^{\circ} \mathrm{C}$ did not differ from fruits stored at $20^{\circ} \mathrm{C}$, different from the 'Nanica', which exhibited a significant reduction.

For 'Prata' fruits kept at $20^{\circ} \mathrm{C}$, the highest values of $\mathrm{L}^{*}$ in the peel occurred for WP, followed by WLNF and last of the other materials, which did not differ (Table 3). WLNF also promoted higher $\mathrm{L}^{*}$ in fruits of the same cultivar maintained at 5 and $10^{\circ} \mathrm{C}$. For 'Nanica' fruits, there were no differences for $\mathrm{L}^{*}$ between protection materials at any storage temperature.

The color intensity $\left(\mathrm{C}^{*}\right)$ was more intense for 'Prata' fruits at $20^{\circ} \mathrm{C}$ with WOP, at $10^{\circ} \mathrm{C}$ with $\mathrm{BW}$ and at $5^{\circ} \mathrm{C}$ with WLNF. For 'Nanica' fruits, independent of storage temperature $\mathrm{C}^{*}$ was higher for WLNF.

Due to CI, the color angle $\left(h^{\circ}\right)$ decreased and shifted towards the reddish region, as a result of the discoloration of peel colour into brown (Hashim et al., 2012) (Table 3), associated with the accumulation of oxidized polyphenols within the vascular tissues (Hashim et al., 2014). Response that occurred to 'Nanica' banana already at $10^{\circ} \mathrm{C}$, while for 'Prata' only without protection fruits exposed to $5^{\circ} \mathrm{C}$. For fruits 'Prata' stored at 10 and $20^{\circ} \mathrm{C}, \mathrm{h}^{\circ}$ was higher with bagging with WLNF, while at $5^{\circ} \mathrm{C}$ there were no

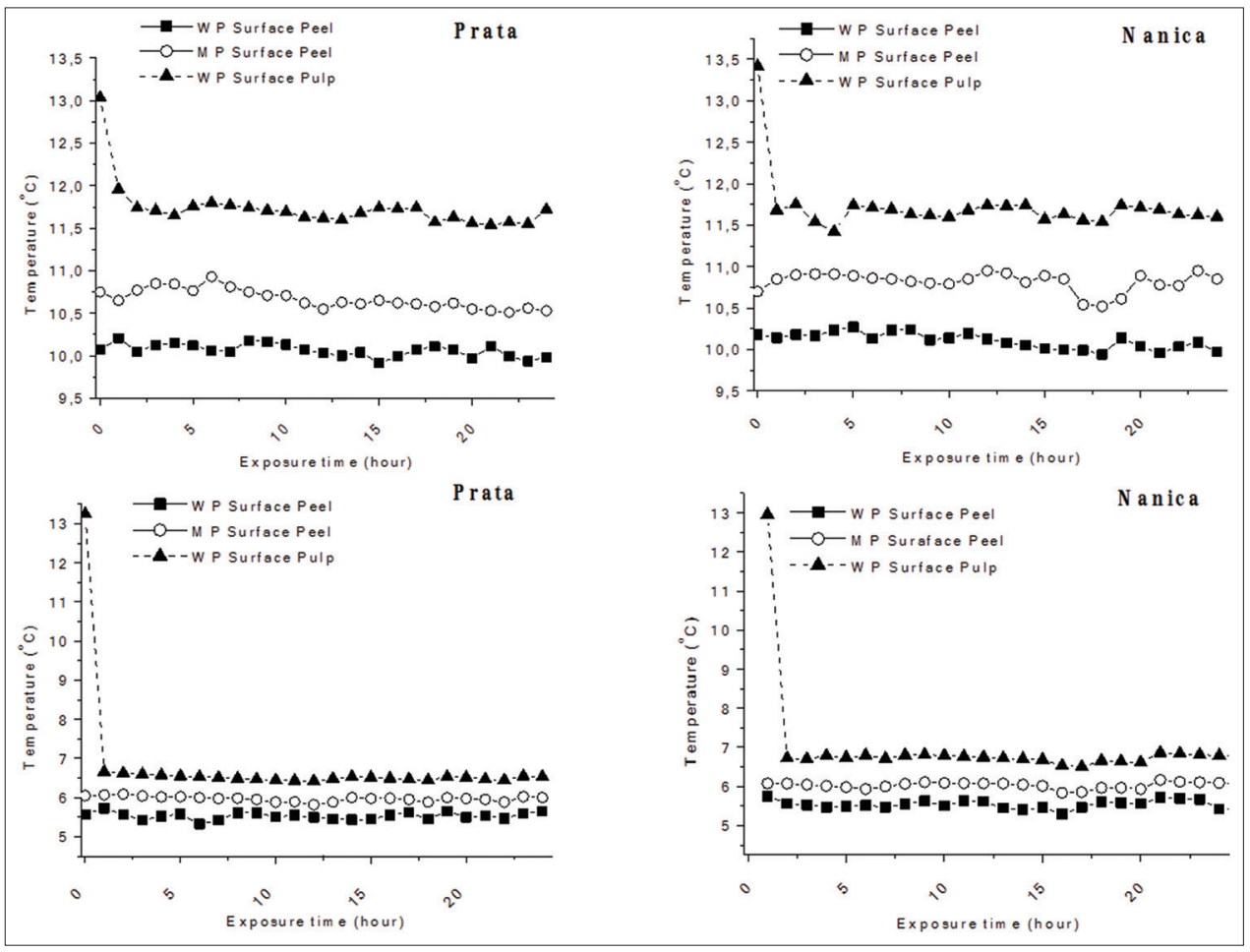

Figure 1. Temperature at the surface of the peel of banana 'Prata' and 'Nanica' without protection (WP Surface Peel), pulp (WP Surface Pulp) and average temperatures on the peel surface of fruits bagged with different materials (MP Surface Peel) during exposure to 10 and $5^{\circ} \mathrm{C}$. 
Table 1: $\mathrm{Cl}$ index of the peel of banana 'Prata' and 'Nanica', depending on temperature

\begin{tabular}{lccc} 
Cultivars & \multicolumn{3}{c}{ Temperature } \\
\cline { 2 - 4 } & $\mathbf{2 0} \mathbf{0}^{\circ} \mathbf{C}$ & $\mathbf{1 0}{ }^{\circ} \mathbf{C}$ & $5^{\circ} \mathbf{C}$ \\
\hline 'Prata' & $1.00 \pm 0.00 \mathrm{~B} \mathrm{~b}$ & $1.00 \pm 0.00 \mathrm{~B} \mathrm{~b}$ & $2.52 \pm 0.55 \mathrm{~B} \mathrm{a}$ \\
'Nanica' & $1.29 \pm 0.46 \mathrm{~A} \mathrm{C}$ & $2.57 \pm 0.79 \mathrm{~A} \mathrm{~b}$ & $3.00 \pm 0.32 \mathrm{~A} \mathrm{a}$ \\
\hline
\end{tabular}

WP, without protection; BTP, blue transparent polyethylene; WNF, white non-woven fabric; WOP, white opaque polyethylene; BW, bubble wrap WLNF, laminated non-woven fabric white. Data are Means \pm standard deviation

Table 2: $\mathrm{Cl}$ index bagged with different protection materials, depending on temperature

\begin{tabular}{lccc}
\hline Protection & \multicolumn{3}{c}{ Temperature } \\
\cline { 2 - 4 } materials & $\mathbf{2 0 ^ { \circ } \mathrm { C }}$ & $\mathbf{1 0 ^ { \circ } \mathrm { C }}$ & $\mathbf{5}^{\circ} \mathrm{C}$ \\
\hline WP & $1.14 \pm 0.35 \mathrm{~A} \mathrm{c}$ & $2.00 \pm 1.00 \mathrm{~A} \mathrm{~b}$ & $3.07 \pm 0.26 \mathrm{~A} \mathrm{a}$ \\
BTP & $1.14 \pm 0.35 \mathrm{~A} \mathrm{c}$ & $1.79 \pm 0.86 \mathrm{AB} \mathrm{b}$ & $2.79 \pm 0.41 \mathrm{~A} \mathrm{a}$ \\
WNF & $1.21 \pm 0.41 \mathrm{~A} \mathrm{C}$ & $1.79 \pm 0.86 \mathrm{AB} \mathrm{b}$ & $2.86 \pm 0.52 \mathrm{~A} \mathrm{a}$ \\
WOP & $1.07 \pm 0.26 \mathrm{~A} \mathrm{C}$ & $1.86 \pm 0.91 \mathrm{AB} \mathrm{b}$ & $2.79 \pm 0.41 \mathrm{~A} \mathrm{a}$ \\
BW & $1.14 \pm 0.35 \mathrm{~A} \mathrm{C}$ & $1.79 \pm 0.80 \mathrm{AB} \mathrm{b}$ & $2.71 \pm 0.45 \mathrm{AB} \mathrm{a}$ \\
WLNF & $1.14 \pm 0.35 \mathrm{~A} \mathrm{C}$ & $1.50 \pm 0.50 \mathrm{~B} \mathrm{~b}$ & $2.36 \pm 0.61 \mathrm{~B} \mathrm{a}$ \\
\hline
\end{tabular}

WP, without protection; BTP, blue transparent polyethylene; WNF, white non-woven fabric; WOP, white opaque polyethylene; BW, bubble wrap; WLNF, white laminated non-woven fabric. Data are means \pm standard deviation. Means followed by the same uppercase letters in the columns and lowercase letters in the lines do not differ from each other by the Tukey test $(p<0.05)$

differences between the protection materials (Table 3). For 'Nanica' fruits, $\mathrm{h}^{\circ}$ at 5 and $20^{\circ} \mathrm{C}$ did not differ between treatments, while at $10^{\circ} \mathrm{C}$, it was higher for WLNF and lower for WP.

Fruits cv. Prata storage at $5^{\circ} \mathrm{C}$ without protection (WP) always showed the lowest values of $\mathrm{L}^{*}, \mathrm{C}^{*} \mathrm{~h}^{\circ}$, indicating that regardless of the nature of the material protection the presence of the bag was beneficial for maintaining the visual quality. Response does not observe in fruits $\mathrm{cv}$. Nanica (Table 3).

Color characteristics presented significant negative correlation $(p<0.01)$ with CI index of the fruit peel 'Prata' $\left(-0.82\right.$ for $L^{*}$ and -0.75 for $\left.C^{*}\right)$ and of the 'Nanica' (-0.83 for $L^{*},-0.74$ and -0.85 for $\left.h^{\circ}\right)$, indicating that the visual analysis of peel browning was adequate.

The incidence of Anthracnose was not influenced by the cultivar $\mathrm{x}$ temperature $\mathrm{x}$ protection material interaction, nor isolated effects of these factors, presenting an average value of 3.51 and $3.85 \%$, respectively, for 'Prata' and 'Nanica', without significant difference $(p<0.01)$. Cladosporium spot occurred only in fruits 'Prata', with an average incidence of $25.39 \%$, unaffected by temperature and protection material $(p<0.01)$.

Crown rot is one of the most important postharvest diseases of banana, very common in bananas of subgroup Cavendish, is caused by several fungi, sometimes in association with other microorganisms such as bacteria (Hailu et al., 2013). Indeed, only 'Nanica' fruits showed Crown rot, which was affected by the interaction temperature and protection material (Table 4). The unfolding of this interaction revealed a lower incidence of Crown rot in fruits stored at $20^{\circ} \mathrm{C}$ with LNFW, followed by WNF, and finally of the other treatments. All fruits stored at 5 and $10^{\circ} \mathrm{C}$ exhibited Crown rot. Cold stress in postharvest promotes reduced resistance to pathogens (Gamal et al., 2010).

The effect of the protection material on the CI index, peel color and incidence of Crown rot may be related to the composition (Tables 2, 3 and 4). BTP, WOP and $\mathrm{BW}$ are composed of low-density polyethylene. WNF and WLNF are made of polypropylene. Polypropylene have higher barrier gases (higher ratio of $\mathrm{CO}_{2}$ to $\mathrm{O}_{2}$ permeability) e water vapor than polyethylene (Mangaraj et al. 2009). Because it is very porous, polypropylene tends to has lower heat transfer, without however has significantly affect the surface temperature of the fruit peel (Figure 1).

The atmosphere with low in $\mathrm{O}_{2}$ and or high in $\mathrm{CO}_{2}$ to influence the metabolism of banana being packaged or the activity of decay-causing organisms to increase storability and/or shelf life (Hailu et al., 2013). Nguyen et al. (2004) observed that that the use of non-perforated polyethylene bags has raised ratio $\mathrm{CO}_{2}$ to $\mathrm{O}_{2}$ and reduced CI symptom in sucrier bananas (Musa AA Group cv. Kluai Khai) stored at $10^{\circ} \mathrm{C}$, response related to lower activity of enzymes phenylalanine ammonia lyase (PAL) and polyphenol oxidase (PPO).

Recently, based on the respiration rate and permeability of the packaging materials, the best suitable packaging films obtained for the modified atmospheric packaging of fruits of Musa balbisiana at different storage temperatures) was found to be polypropylene, and polyvinyl chloride film (Ghosh and Dash, 2018).

Despite possible differences in moisture and gas content inside the bagging, there were no differences in shelf life and mass loss, as well as in other physicochemical characteristics, between the protection materials. Shelf life has not prolonged (Table 4), possibly because after exposure to low temperature the fruits were kept at $20^{\circ} \mathrm{C}$, temperature that allows high metabolic activity. Exposure to low temperature $\left(5\right.$ and $10^{\circ} \mathrm{C}$ ) also did not affect the ripening and conversion of starch to soluble sugars, though the pulp has reached the stress temperature (Figure 1). 
Table 3: Brightness $\left(\mathrm{L}^{*}\right)$, chromaticity $\left(\mathrm{C}^{*}\right)$, hue angle $\left(\mathrm{h}^{\circ}\right)$ of the peel of banana 'Prata' and 'Nanica' bagged with different protection materials, depending on temperature

\begin{tabular}{|c|c|c|c|c|}
\hline \multirow[t]{2}{*}{ Protection materials } & \multirow[t]{2}{*}{ Cultivars } & \multicolumn{3}{|c|}{ Temperature } \\
\hline & & $20^{\circ} \mathrm{C}$ & $10^{\circ} \mathrm{C}$ & $5^{\circ} \mathrm{C}$ \\
\hline & & & $L^{*}$ & \\
\hline \multirow[t]{2}{*}{ WP } & 'Prata' & $75.52 \pm 0.44 \mathrm{~A}$ a A & $72.12 \pm 0.23 \mathrm{~A} \mathrm{~b} \mathrm{~B}$ & $62.12 \pm 0.10 \mathrm{~A}$ c D \\
\hline & 'Nanica' & $70.46 \pm 0.59 \mathrm{~B}$ a A & $64.08 \pm 0.46 \mathrm{~B} \mathrm{~b} \mathrm{~A}$ & $59.96 \pm 0.26$ B c A \\
\hline \multirow[t]{2}{*}{ BTP } & 'Prata' & $72.71 \pm 0.16 \mathrm{~A}$ a $\mathrm{C}$ & $72.23 \pm 0.32 \mathrm{~A}$ a B & $67.96 \pm 0.75$ A b C \\
\hline & ‘Nanica' & $70.17 \pm 0.85 \mathrm{~B}$ a A & $64.13 \pm 0.39 \mathrm{~B} \mathrm{~b} \mathrm{~A}$ & $59.75 \pm 0.50 \mathrm{~B} \mathrm{c} \mathrm{A}$ \\
\hline \multirow[t]{2}{*}{ WNF } & 'Prata' & $72.94 \pm 0.15 \mathrm{~A}$ a C & $72.31 \pm 0.29$ A a B & $68.45 \pm 0.38 \mathrm{~A}$ b BC \\
\hline & 'Nanica' & $69.88 \pm 0.17 \mathrm{~B}$ a A & $64.16 \pm 0.30 \mathrm{~B} \mathrm{~b} \mathrm{~A}$ & $60.02 \pm 0.60 \mathrm{~B} \mathrm{c} \mathrm{A}$ \\
\hline \multirow[t]{2}{*}{ WOP } & 'Prata' & $72.49 \pm 0.15 \mathrm{~A}$ a C & $72.25 \pm 0.09 \mathrm{~A}$ a B & $68.63 \pm 0.30 \mathrm{~A} \mathrm{~b} \mathrm{~B}$ \\
\hline & 'Nanica' & $69.96 \pm 0.39 \mathrm{~B}$ a A & $64.37 \pm 0.34 \mathrm{~B} \mathrm{~b} \mathrm{~A}$ & $60.34 \pm 0.35$ B c A \\
\hline \multirow[t]{2}{*}{ BW } & 'Prata' & $72.97 \pm 0.20 \mathrm{~A}$ a C & $72.47 \pm 0.29 \mathrm{~A}$ a B & $68.95 \pm 0.15 \mathrm{~A} \mathrm{~b} \mathrm{~B}$ \\
\hline & 'Nanica' & $70.07 \pm 0.45 \mathrm{~B}$ a A & $64.16 \pm 0.55 \mathrm{~B} \mathrm{~b} \mathrm{~A}$ & $60.36 \pm 0.69$ B c A \\
\hline \multirow[t]{3}{*}{ WLNF } & 'Prata' & $73.85 \pm 0.48 \mathrm{~A}$ a B & $73.69 \pm 0.49 \mathrm{~A}$ a $\mathrm{A}$ & $73.31 \pm 0.09 \mathrm{~A}$ a $\mathrm{A}$ \\
\hline & 'Nanica' & $70.28 \pm 0.41 \mathrm{~B}$ a A & $64.08 \pm 0.53 \mathrm{~B} \mathrm{~b} \mathrm{~A}$ & $59.89 \pm 0.71 \mathrm{~B} \mathrm{c} \mathrm{A}$ \\
\hline & & & $\mathrm{C}^{*}$ & \\
\hline \multirow[t]{2}{*}{ WP } & 'Prata' & $54.15 \pm 0.12 \mathrm{~A}$ a B & $53.32 \pm 0.39$ A b B & $41.24 \pm 0.73$ A c D \\
\hline & 'Nanica' & $47.68 \pm 0.70 \mathrm{~B}$ a E & $45.09 \pm 0.78$ B b D & $31.87 \pm 0.50$ B c D \\
\hline \multirow[t]{2}{*}{ BTP } & 'Prata' & $54.24 \pm 0.10 \mathrm{~A}$ a B & $54.15 \pm 0.14 \mathrm{~A}$ a B & $49.32 \pm 0.56$ A b C \\
\hline & 'Nanica' & $48.61 \pm 0.44 \mathrm{~B}$ a D & $\begin{array}{c}46.45 \pm 0.79 \mathrm{~B} \mathrm{~b} \\
\mathrm{BC}\end{array}$ & $34.28+0.45 \mathrm{~B} \mathrm{c} \mathrm{C}$ \\
\hline \multirow[t]{2}{*}{ WNF } & 'Prata' & $53.96 \pm 0.52 \mathrm{~A}$ a B & $51.43 \pm 0.58$ A b C & $49.02 \pm 0.30 \mathrm{~A} \mathrm{c} \mathrm{C}$ \\
\hline & 'Nanica' & $49.26 \pm 0.52 \mathrm{~B}$ a CD & $46.02 \pm 0.64 \mathrm{~B} \mathrm{~b} \mathrm{C}$ & $34.95 \pm 0.52 \mathrm{~B} \mathrm{c} \mathrm{BC}$ \\
\hline \multirow[t]{2}{*}{ WOP } & 'Prata' & $55.72 \pm 0.46 \mathrm{~A}$ a A & $51.53 \pm 0.54 \mathrm{~A} \mathrm{~b} \mathrm{C}$ & $48.96 \pm 0.35 A$ c C \\
\hline & 'Nanica' & $49.79 \pm 0.95 \mathrm{~B}$ a $\mathrm{AB}$ & $46.90 \pm 0.68$ B b B & $34.70 \pm 1.25$ В с BC \\
\hline \multirow[t]{2}{*}{ BW } & 'Prata' & $54.45 \pm 0.30 \mathrm{~A}$ a B & $55.03 \pm 0.45 \mathrm{~A}$ a $\mathrm{A}$ & $50.29 \pm 0.51$ A b B \\
\hline & 'Nanica' & $49.53 \pm 0.24$ B a C & $47.12 \pm 0.24$ B b B & $35.21 \pm 0.24$ B c B \\
\hline \multirow[t]{3}{*}{ WLNF } & 'Prata' & $54.02 \pm 0.21 \mathrm{~A} \mathrm{~b} \mathrm{~B}$ & $53.36 \pm 0.17$ A b B & $55.76 \pm 0.61 \mathrm{~A}$ a A \\
\hline & 'Nanica' & $50.58 \pm 0.50 \mathrm{~B}$ a A & $48.2 \pm 60.43 \mathrm{~B} \mathrm{~b} \mathrm{~A}$ & $36.39 \pm 0.62$ B c A \\
\hline & & & $h^{\circ}$ & \\
\hline \multirow[t]{2}{*}{ WP } & 'Prata' & $89.13 \pm 0.10 \mathrm{~A}$ a B & $89.05 \pm 0.64 \mathrm{~A} \mathrm{a} \mathrm{C}$ & $83.23 \pm 0.31 \mathrm{~A} \mathrm{~b} \mathrm{~B}$ \\
\hline & 'Nanica' & $88.23 \pm 0.15 \mathrm{~B}$ a A & $\begin{array}{c}83.57 \pm 0.52 \mathrm{~B} b \\
A B\end{array}$ & $82.24 \pm 0.69 \mathrm{~B} \mathrm{c} \mathrm{A}$ \\
\hline \multirow[t]{2}{*}{ BTP } & 'Prata' & $89.43 \pm 0.13 \mathrm{~A}$ a $\mathrm{AB}$ & $\begin{array}{c}89.35 \pm 0.19 \mathrm{~A} a \\
A B\end{array}$ & $89.82 \pm 0.25 \mathrm{~A}$ a A \\
\hline & 'Nanica' & $88.53 \pm 0.28 \mathrm{~B}$ a A & $\begin{array}{c}83.69 \pm 0.38 \mathrm{~B} b \\
A B\end{array}$ & $82.41 \pm 0.62$ B c A \\
\hline \multirow[t]{2}{*}{ WNF } & 'Prata' & $89.76 \pm 0.20 \mathrm{~A}$ a $\mathrm{AB}$ & $89.24 \pm 0.18 \mathrm{~A}$ a C & $89.77 \pm 0.07 \mathrm{~A}$ a $\mathrm{A}$ \\
\hline & 'Nanica' & $88.56 \pm 0.74 \mathrm{~B}$ a A & $\begin{array}{c}83.62 \pm 0.44 \mathrm{~B} \mathrm{~b} \\
\mathrm{AB}\end{array}$ & $81.99 \pm 0.61 \mathrm{~B} \mathrm{c} \mathrm{A}$ \\
\hline \multirow[t]{2}{*}{ WOP } & 'Prata' & $89.31 \pm 0.16 \mathrm{~A}$ a $\mathrm{AB}$ & $\begin{array}{c}89.64 \pm 0.20 \mathrm{~A} \mathrm{a} \\
\mathrm{AB}\end{array}$ & $89.79 \pm 0.09 \mathrm{~A}$ a A \\
\hline & 'Nanica' & $88.17 \pm 0.55 \mathrm{~B}$ a A & $84.06 \pm 0.40 \mathrm{~B} \mathrm{~b} \mathrm{~A}$ & $82.34 \pm 0.84$ B c A \\
\hline \multirow[t]{2}{*}{ BW } & 'Prata' & $89.90 \pm 0.08 \mathrm{~A}$ a $\mathrm{AB}$ & $89.06 \pm 0.40 \mathrm{~A}$ a C & $89.69 \pm 0.19 \mathrm{~A}$ a A \\
\hline & 'Nanica' & $88.65 \pm 0.60 \mathrm{~B}$ a A & $83.28 \pm 0.57$ B b B & $82.21 \pm 0.57 \mathrm{~B} \mathrm{c} \mathrm{A}$ \\
\hline \multirow[t]{2}{*}{ WLNF } & 'Prata' & $89.92 \pm 0.18 \mathrm{~A}$ a A & $89.96 \pm 0.19 \mathrm{~A}$ a $\mathrm{A}$ & $89.68 \pm 0.18 \mathrm{~A}$ a $\mathrm{A}$ \\
\hline & 'Nanica' & $88.63 \pm 0.80 \mathrm{~B}$ a A & $84.11 \pm 0.21$ B b A & $82.06 \pm 0.94 \mathrm{~B} \mathrm{c} \mathrm{A}$ \\
\hline
\end{tabular}

WP, without protection; BTP, blue transparent polyethylene; WNF, white non-woven fabric; WOP, white opaque polyethylene; BW, bubble wrap; WLNF, white laminated non-woven fabric. Data are means \pm standard deviation. Means followed by the same uppercase letters (normal or underlined or bold) in the column and lowercase letters in the line do not differ from each other by Tukey test $(p<0.05)$

This fact may be related to the stress temperature and duration or to the type of the tissue. The shelf life, mass loss, total soluble solid, $\mathrm{pH}$, titratable acidity, soluble sugars and starch in the pulp were affected only by the cultivar, with mean values characteristic of each genomic group (Table 5). 
Table 4: Incidence of Crown rot of the peel of banana 'Nanica' bagged with different protection materials, depending on temperature

\begin{tabular}{lccc}
\hline Protection & \multicolumn{3}{c}{ Temperature } \\
\cline { 2 - 4 } materials & $\mathbf{2 0 ^ { \circ } \mathrm { C }}$ & $\mathbf{1 0 ^ { \circ } \mathbf { C }}$ & $\mathbf{5}^{\circ} \mathbf{C}$ \\
\hline WP & $100.00 \pm 0.00 \mathrm{~A} \mathrm{a}$ & $100.00 \pm 0.00 \mathrm{~A}$ a & $100.00 \pm 0.00 \mathrm{~A} \mathrm{a}$ \\
BTP & $100.00 \pm 0.00 \mathrm{~A} \mathrm{a}$ & $100.00 \pm 0.00 \mathrm{~A}$ a & $100.00 \pm 0.00 \mathrm{~A} \mathrm{a}$ \\
WNF & $85.71 \pm 0.17 \mathrm{~B} \mathrm{~b}$ & $100.00 \pm 0.00 \mathrm{~A}$ a & $100.00 \pm 0.00 \mathrm{~A} \mathrm{a}$ \\
WOP & $100.00 \pm 0.00 \mathrm{~A} \mathrm{a}$ & $100.00 \pm 0.00 \mathrm{~A}$ a & $100.00 \pm 0.00 \mathrm{~A} \mathrm{a}$ \\
BW & $100.00 \pm 0.00 \mathrm{~A} \mathrm{a}$ & $100.00 \pm 0.00 \mathrm{~A}$ a & $100.00 \pm 0.00 \mathrm{~A} \mathrm{a}$ \\
WLNF & $71.43 \pm 0.41 \mathrm{C} \mathrm{b}$ & $100.00 \pm 0.00 \mathrm{~A}$ a & $100.00 \pm 0.00 \mathrm{~A} \mathrm{a}$ \\
\hline
\end{tabular}

WP, without protection; BTP, blue transparent polyethylene; WNF, white non-woven fabric; WOP, white opaque polyethylene; BW, bubble wrap; WLNF, white laminated non-woven fabric. Data are means \pm standard deviation. Means followed by the same uppercase letters in the column and lowercase letters in the line do not differ from each other by Tukey test $(p<0.05)$. Means followed by the same uppercase letters in the column and lowercase letters in the line do not differ from each other by Tukey test $(p<0.05)$

Table 5: Shelf life (SL), mass loss (ML), total soluble solid (TSS), pH, titratable acidity (TA), soluble sugars (SS), starch (STA) and firmness (F) of the banana 'Prata' and 'Nanica.

\begin{tabular}{lcccc}
\hline Cultivars & SL days & ML $\%$ & TSS $^{\circ}$ Brix & pH \\
\hline 'Prata' & $24.12 \pm 2,94$ A & $9.65 \pm 1,28$ A & $22.75 \pm 0,76$ A & $4.93 \pm 0,07$ A \\
'Nanica' & $12.33 \pm 1,45$ B & $7.54 \pm 0,77$ B & $20.14 \pm 1,69$ B & $4.27 \pm 0,10$ B \\
\hline & TA $^{*} \%$ & SS $\%$ & STA $\%$ & F N \\
\hline 'Prata' & $0.71 \pm 0,05$ B & $0.31 \pm 0,01$ A & $17.36 \pm 1,32$ B & $11.96 \pm 1,07$ \\
'Nanica' & $0.60 \pm 0,08$ A & $0.26 \pm 0,02$ B & $21.50 \pm 0,96$ A & $11.32 \pm 1,14$ \\
\hline
\end{tabular}

The symptoms of CI are dependent on the genomic group (der Agopian et al., 2011). In this study cultivar 'Prata' was more tolerant to CI than 'Nanica' (Table 1). Really, in Brazil, the cv. Nanicão, a member of the AAA group, is commercially relevant but less tolerance to low temperatures than Prata, the cultivar of the $\mathrm{AAB}$ group (der Agopian et al., 2011). The B genome appears to confer cold resistance (der Agopian et al., 2011). Goldfinger' banana $(\mathrm{AAAB})$ showed tolerance keeping $\mathrm{L}^{*}$ and $\mathrm{h}^{\circ}$ of the peel unchanged even when submitted to storage at $10^{\circ} \mathrm{C}$, compared to control $20^{\circ} \mathrm{C}$.

It is suggested to carry out new studies using microperforated LNWF of different thicknesses, in order to extend the shelf life of the banana with a lower temperature than usual $\left(13^{\circ} \mathrm{C}\right)$, for cv. Prata between 5 and $10^{\circ} \mathrm{C}$ and cv. Nanica between 10 and $13^{\circ} \mathrm{C}$.

\section{CONCLUSIONS}

The different protection materials kept the temperature inside at $1^{\circ} \mathrm{C}$ higher than environment. The critical temperature for occurrence of chilling injury was $5^{\circ} \mathrm{C}$ for 'Prata' banana and $10^{\circ} \mathrm{C}$ for 'Nanica' banana. In terms of chilling injury and peel color, the laminated non-woven fabric white was the best material. Other physicochemical characteristics were not influenced by low temperature and protection material, only by cultivar.

\section{ACKNOWLEDGMENTS}

To FAPESP, for its financial support; to banana producer Silvio Guatura Romão for the cession of the area; and for José Alberto dos Santos, José Carlos de Mendonça and Dr. Wilson da Silva Moraes for technical support.

\section{AUTHORS' CONTRIBUITIONS}

Conceived and designed the experiments: JDL. Performed the experiments: JDL, DER, ENG. Analysed the data: JDL, SHMGS. Contributed analysis tools: RAK, ENG. Prepared the paper: JDL, SHMGS.

\section{REFERENCES}

AOAC. 2005. Official Methods of Analysis Of International. Washington, p. 1018.

der Agopian, R. G., F. H. G. Peroni-Okita, C. A. Soares, J. A. Mainardi, J. R. O. do Nascimento, B. R. Cordenunsi, F. M. Lajolo and E. Purgatto. 2011. Low temperature induced changes in activity and protein levels of the enzymes associated to conversion of starch to sucrose in banana fruit. Postharvest Biol. Technol. 62(2): 133-140.

Gamal, E., W. Ning and V. Clement. 2009. Detecting chilling injury in red delicious apple using hyperspectral imaging and neural networks. Postharvest Biol. Technol. 52: 1-8.

Ghosh, T and K. K. Dash. 2018. Respiration rate model and modified atmosphere packaging of bhimkol banana. Eng. Agric. Environ. Food. 11(3). In press.

Hailu, M., T. S. Workneh and D. Belew. 2012. Effect of packaging materials on the quality of banana cultivars. Afr. J. Agrc. Res. 7(7): 1226-1237.

Hailu, M., T. S. Workneh and D. Belew. 2013. Review on postharvest technology of banana fruit. Afr. J. Biotechnol. 12(7): 635-647.

Hashim, N., R. B. Janius, R. A. Rahman, A. Osman and M. Zude. 2012. Kinetic model for colour changes in bananas during the appearance of chilling injury symptoms. Food Bioproc. Tech. 5(8): 2952-2963.

Hashim, N., R. B. Janius, L. Baranyai, R. A. Rahman, A. Osman, M. Shitan and M. Zude. 2014. Changes of backscattering parameters during chilling injury in bananas. J. Eng. Sci. Tech. 9(3): 314-325.

Hodge J. E and B. R. Hodfreiter. 1962. Determination of reducing sugars and carbohydrate. In: Wilster R. C and M. I. Wolfron, (Ed.). Methods in Carbohydrates Chemistry, Academic Press, N. Y. v.1. pp. 380-398.

Kondo, S., M. Kittikorn and S. Kanlayanarat. 2005. Preharvest antioxidant activities of tropical fruit and the effect of low temperature storage on antioxidants and jasmonates. Postharvest Biol. Technol. 36(3): 309-318.

Mangaraj, S., T. K. Goswami, S. K. Giri and M. K. Tripathi. 2009. Applications of plastic films for modified atmosphere packaging of fruits and vegetables: A review. Food Eng Rev. 1: 133. 
McCready, R. M., J. Guggolz, V. Silviera and H. S. Owens. 1950. Determination of starch and amylase in vegetales. Anal. Chem. 22(9): 1156-1158.

Nguyen, T. B. T., S. Ketsa and W. G. van Doorn. 2004. Effect of modified atmosphere packaging on chilling-induced peel browning in banana. Postharvest Biol. Technol. 31: 313-317.

Patel, R. Z (1970) A note on the seasonal variations in starch content of different parts of Arabica coffee trees. East Afr. Agric. 36: 1-4.

Sahay S., P. K. Mishra, K. Rashmi, M. F. Ahmad and A. K. Choudhary. 2015. Effect of post harvest application of chemicals and different packaging materials on shelf-life of banana (Musa spp.) cv Robusta. Indian J. Agric. Sci. 85(8): 1042-1045.

Sahay S., P. K. Mishra, K. Rashmi and M. F. Ahmad. 2017. Postharvest application of $\mathrm{CaCl}_{2}$ and wrapping materials on shelf-life of banana cv. Robusta. Indian J Hort. 74(3): 462-465.

Sen, C., H. N. Mishra and P. P. Srivastav. 2012. Modified atmosphere packaging and active packaging of banana (Musa spp.): A review on control of ripening and extension of shelf life. J. Stored Prod. Postharvest Res. 3(9): 122-132.
Siqueira, C. L., M. L. M. Rodrigues, G. P. Mizobutsi, P. G. Santos, W. F. Mota, E. H. Mizobutsi and G. B. Oliveira. 2010. Características físico-quimicas, análise sensorial e conservação de frutos de cultivares de bananeira resistentes à Sigatoka-negra. Rev. Ceres. 57(5): 673-678.

Siqueira, C. L., O. P. Lopes, P. S. C. Batista, M. L. M. Rodrigues, M. F. P. Serpa, G. P. Mizobutsi, and W. F. Mota. 2017. Atmosfera modificada e refrigeração na conservação pós-colheita de bananas. 'Tropical' e 'Thap Maeo' Nativa. 5(3):157-162.

Tressler, D. L and Joslyn, M.A. 1961. Fruits and vegetables juiceprocessing technology. AVI Publishing, Wetsport, Connecticut, USA.

von Loesecke, H and W. Bananas. 1950. $2^{\text {nd }}$ ed. Interscience Publish Inc., New York.

Wu B., Q. Guo, Q. LI, Y. Ha, X. Li and W. Chen. 2014. Chen Impact of postharvest nitric oxide treatment on antioxidant enzymes and related genes in banana fruit in response to chilling injury. Postharvest Biol. Technol. 92: 157-163. 